\title{
Dynamics of sedimentary Capibaribe River bed after deepening dredging
}

\section{Dinâmica sedimentar do leito do Rio Capibaribe após dragagens de aprofundamento}

\author{
Rafael Roney Camara de Melo $^{1}$ and José Roberto Gonçalves de Azevedo ${ }^{1}$ \\ ${ }^{1}$ Universidade Federal de Pernambuco, Recife, PE, Brazil \\ E-mails: rafael.roney@yahoo.com.br (RRCM),jrga@ufpe.br (JRGA)
}

Received: March 02, 2016 - Revised: August 07, 2016 - Accepted: August 26, 2016

\begin{abstract}
The growth of urban centers in the country are increasingly dependent on the adoption of new mobility options, and before this need was developed and initiated a project to build a river corridor passenger in a part of the Capibaribe River in the city of Recife-PE. For the implementation of a navigation channel deepening are needed dredging to define a geometry of the bed of the river compatible with the needs of ships that will traverse the channel. The monitoring of dredging is done with the constant bathymetric surveys where the information volumes of dredged sediments are removed, aiming to also check the temporal behavior of deposition and erosion processes. In this context, the work aimed to evaluate the geometry of the Capibaribe river bed after the deepening dredging, using data from bathymetric surveys at different times for making longitudinal and transverse profiles, and create digital models of depth to extract information about the deposition/aggradation or erosion/removing sediments and their respective volumes. Early Profile Capibaribe river showed mild slope and heterogeneity in the bottom of the form, especially after kilometer five, with trends of deposition/aggradation downstream of the confluence region with tax arising from the weir Apipucos and upstream of the winding sections in local enlargement of the cross section, and the amount of the fork located at kilometer nine. The scenarios after the dredging to deepen indicate places with predominance of erosion and other sedimentation processes. They compared the longitudinal and transverse profiles of two areas located in western shipping channel, one with 350 meters and over 1000 meters, where it was found that the area 1 to erosion/sediment removal exceeded sedimentation/aggradation, indicating the occurrence of dredging the interval between the two surveys linked to the natural processes. In the study area 2 the sedimentation/aggradation exceeded the removal/erosion, with a volume equivalent to $1 \mathrm{~cm}$ thickness. The aggradation occur homogeneously in the navigation channel, while erosion was located on the banks, more intensely on the right bank of the river.
\end{abstract}

Keywords: Capibaribe River; Dredging; Sediment.

\section{RESUMO}

O crescimento dos centros urbanos no país demanda cada vez mais a adoção de novas opções de mobilidade, e diante desta necessidade foi elaborado e iniciado um projeto que visa construir um corredor fluvial de passageiros em uma parte do rio Capibaribe na cidade do Recife-PE. Para a implantação de um canal de navegação são necessárias dragagens de aprofundamento para definir uma geometria do leito do rio compatível com as necessidades das embarcações que irão percorrer o canal. O acompanhamento das dragagens se faz com os constantes levantamentos batimétricos de onde são retiradas as informações dos volumes de sedimentos dragados, tendo como objetivo também verificar o comportamento temporal dos processos de deposição e erosão. Nesse contexto, o trabalho teve como objetivo avaliar a geometria do leito do rio Capibaribe após as dragagens de aprofundamento, utilizando dados de levantamentos batimétricos em períodos distintos para confeccionar perfis longitudinais e transversais, e criar modelos digitais de profundidade para extração de informações sobre a deposição/agradação ou erosão/remoção de sedimentos e os seus respectivos volumes. O perfil primitivo do rio Capibaribe apresentou suave declividade e heterogeneidade nas formas do fundo, principalmente após o quilômetro cinco, com tendências de deposição/agradação a jusante da região de confluência com tributário advindo do açude de Apipucos e a montante dos trechos sinuosos, nos locais de alargamento da seção transversal, e a montante da bifurcação situada no quilometro nove. Os cenários após as dragagens de aprofundamento indicam locais com predominância dos processos erosivos e em outros, processos de sedimentação. Foram comparados os perfis longitudinais e transversais de duas áreas situadas no canal de navegação 
oeste, uma com 350 metros e outra com 1000 metros, onde se verificou que na área 1 a erosão/remoção de sedimentos superou a sedimentação/agradação, indicando a ocorrência de dragagens no intervalo entre os dois levantamentos associado aos processos naturais. $\mathrm{Na}$ área de estudo 2 o processo de sedimentação/agradação superou o de remoção/erosão, com um volume equivalente a uma camada de $1 \mathrm{~cm}$ de espessura. A agradação ocorreu de forma homogênea no canal de navegação, enquanto que a erosão localizou-se nas margens, mais intensamente na margem direita do rio.

Palavras-chave: Rio Capibaribe; Dragagem; Sedimentos.

\section{INTRODUCTION}

In Brazil, the road transport prevails, although it has geographic traits that favor the inland waterway transport and by rail (OLIVEIRA, 2010). About the inland waterway transport of passengers, it is concentrated in the North region of the country, mainly in the Amazonas State, due to the abundance of the river network.

The growth of the metropolitan area in the city of Recife, associated to the planning issues, made the government notice in the last years alternatives to the urban mobility, like the fast transport corridors and inland waterway transport. One of the projects proposed by the City Secretariat of the Pernambuco State was to turn a part of the Capibaribe river navigable.

For the achievement of a river navigability project, some hydrographic surveys are indispensable, intending to collect topographic data, geodesic, oceanographic, meteorological, bathymetric, hydrological, geomorphological, aerophotogrammetric and remote sensing (ARENTZ, 2009). Through these hydrographic surveys, the geometrical characteristics of the Fairway, like the width and depth. There are many ways to obtain the bathymetry data, which will depend on the goals of the survey. But the more common are the direct measurement using a single beam echo-sounder from a mono and/or multibeam (FERREIRA, 2013).

The engineering techniques utilized to implement an inland waterway corridor consist basically in the construction of stations for the boarding of passengers, completion of river works and river dredging services. This last one, consists in the excavation, removal, transport and adequate display of soil and/or rocks, submerged, by means of equipment (mechanical or hydraulic) in tides, estuaries and rivers (ALFREDINI, 2005), being a common service also in the drainage channels for removal of sediment and trash deposited in the channel bottom. The modification procedure of the river channel is called 'plumbing', and consists in the broadening and deepening of the trough, rectifying the channel, construction of dikes, protection of banks and removal of obstacles in the channel (GUERRA; CUNHA, 2012).

The Dredging brings a number of implications to the environment. The sediment removal can alter the quality of the water, causing impacts on microorganisms, and the alteration of the depth can also alter the security of the navigation and the local hydrodynamics (OLIVEIRA, 2010). One of the consequences of the hydrodynamics alteration is the greater drag of sediments and, as a result, the erosion in the margins.

Knowing the geometry of a riverbed is important to verify the mechanics of the sediment transportation, for hydrodynamics simulations, as well as preventing the behavior of a longitudinal or transverse profile in the face against dredging activities, navigation and extreme hydrological events (OLIVEIRA, 2010; STRASSER, 2002; SALEH et al., 2013)

The knowledge of the sediment dynamics of the riverbed is important for the evaluation of the navigation conditions of a river. And such study becomes important for the prediction and evaluation of the periodicity in the dredging execution.

The rectifications done in a river diminish it's length, roughness of the riverbed, and increase the gradient, causing considerable impact in the environment, such as an increase in the solid load downstream of the rectified channel, susceptibility to erosion in the case of torrential events in the regime, and a resume of the erosion in the affluents (GUERRA; CUNHA, 2012).

The unbalance of the solid load occurs when there are violent alterations in the regime, like, for instance, the construction of a dam, which causes silting upstream and degradations of the riverbed and downstream margins. Interventions in watercourses like dredgings and other river works alter the regime and consequently the solid load (CARVALHO, 2008).

The measure of the solid load of the riverbed presents a bigger complexity when compared to the solid load in suspension, having most of the expressions determined in experimental conditions (ALFREDINI, 2005).

In the transport of sediments of the riverbed of great canals and rivers, mainly sandy ones, like the Capibaribe river, there are some difficulties, mostly because of the dynamic conditions of the riverbed-water interface, more complicated in the estuarine regions with a strong tide influence (MILLIMAN; MEADE apud NITTROUER; ALLISON; CAMPANELLA, 2008).

Given the shortage and the importance of the studies of sand transport in th riverbeds, Nittrouer, Allison and Campanella (2008) analyzed the transport of sediments of the riverbed, associated to the migration of dunes in localized areas along a section of 15 kilometers of the Mississippi river, utilizing data from the multibeam echobathymeter and river downloads.

Luo et al. (2007) identified the morphological and hydrological impacts of the Perl River's delta in China, caused by the extraction of sandy sediment of the riverbed, with the intent of using it in construction. The negative impacts observed were the increase in the degree of stability of the margins and a bigger water intrusion coming from the sea. Positively, an improvement in the navigation conditions and a reduction in the risk of floodings were observed.

Pinter et al (2004) identified in a section of 498 kilometers of the medium and high Mississippi river space and temporal patterns, with recurrent sediment depositions and high numbers of maintenance dredgings, through historical records of the dredgings achieved, and classified the depositions for the following situations: (1) Waterfalls and bifurcations of the canal; (2) Tax 
junctions; (3) Curves of meanders; (4) Rectilinear sections and; (5) Proximity to big engineering structures.

Gireli and Vendrame (2012) also analyzed the historical data of the dredgings made for the deepening of the access channel to the Santos Port and identified that a section of the canal is responsible for $60 \%$ of all the volume of dredged material, focusing in the economic viability, the rate of silting and the depth maintenance.

In the works of Almeida (2012), Martins (2004) and Strasser (2002) were calculated the download of sediments of the riverbed through bathymetric surveys in distinct periods, being calculated by the displacement of the background shapes (dunes), or by the difference of the riverbed surfaces (NITTROUER; ALLISON; CAMPANELLA, 2008).
Within this context, the present work aims to evaluate the sediment dynamics of the riverbed of the lower Capibaribe, after the deepening dredging works done for navigation, utilizing a series of bathymetric data to verify the occurrence of depositions or erosions. As well as the characteristics of the navigation channel and possible impacts related to deepening.

\section{METODOLOGY}

\section{Study area}

The area of study is located in the hydrographic basin of the Capibaribe river (Figure 1), which presents an area of $7.454,88 \mathrm{~km}^{2}$. It is located between the coordinates $07^{\circ} 41^{\prime} 20^{\prime \prime}$ and

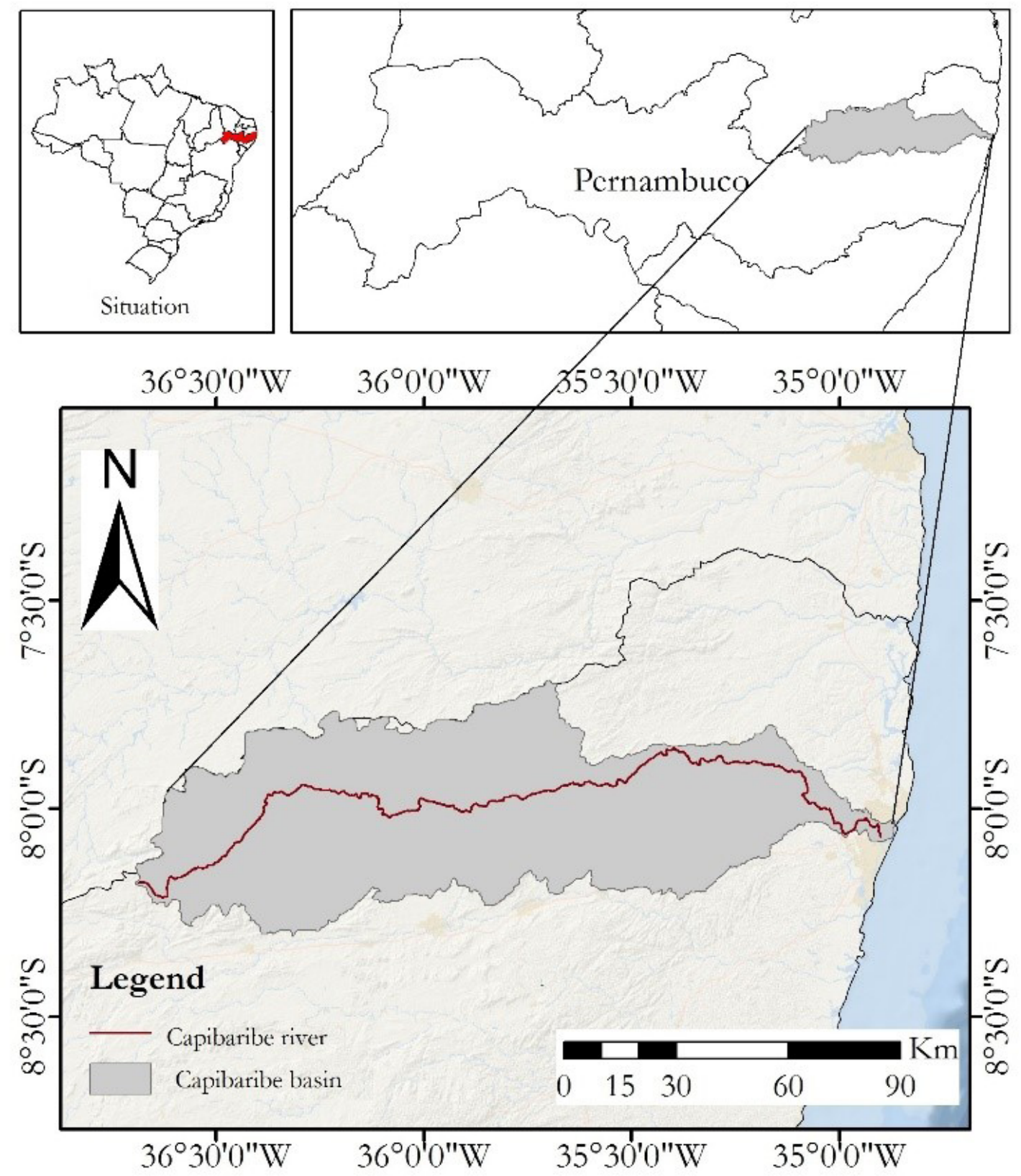

Figure 1. Study area: Capibaribe river. 
$08^{\circ} 19^{\prime} 30^{\prime \prime}$ south latitude, and $34^{\circ} 51^{\prime} 00^{\prime \prime}$ and $36^{\circ} 41^{\prime} 58^{\prime \prime}$ west longitude, limiting itself to the North with the state of Paraíba, the Goiana river basin, and a group of basins of small coastal rivers, to the south with the basin of Ipojuca river, to the east with the Atlantic Ocean, and to the west with the state of Paraíba and the basin of the Ipojuca river (APAC, 2014).

The source of the Capibaribe river is located in the chevron of the Poção and Jataúba counties, becoming perennial only in Limoeiro County, and runs about $280 \mathrm{~km}$ to the river mouth in Recife. When the Capibaribe river reaches the coastal plain, in Recife, it forms an estuary, whose mouth is located in the Port of Recife (MONTEIRO et al., 2011).

The sediment present in the studied riverbed of Capibaribe river is composed mainly by sand, representing about $67 \%$ of the material (GOMES JUNIOR, 2012). The average annual discharge of the Capibaribe river, between 1990 and 2014 (Figure 2), was $10.58 \mathrm{~m}^{3} / \mathrm{s}$. And in the last years after the beginning of the dredging operations between 2013 and 2014, presented bigger flows registered in the period between May and July, and peak of $117.93 \mathrm{~m}^{3} / \mathrm{s}$ in the period of June, 2013 (ANA, 2015).

\section{Navigation channel}

The navigability Project of the Capibaribe river was conceived for the public transportation of passengers, divided in three sections: west section, north section and south section. Only the west section received the deepening dredging works, with about 11 kilometers, which starts in kilometer 0 , around BR-101 crossroad with the Capibaribe river, until kilometer 11, next to Recife's central metro station downtown, and will count with 5 river stations distributed alongside the channel.

The dredgings to the west channel began in the year 2013, extending themselves until the middle of 2014, when they were interrupted, with almost all the extension of the channel dredged until the projected elevation.

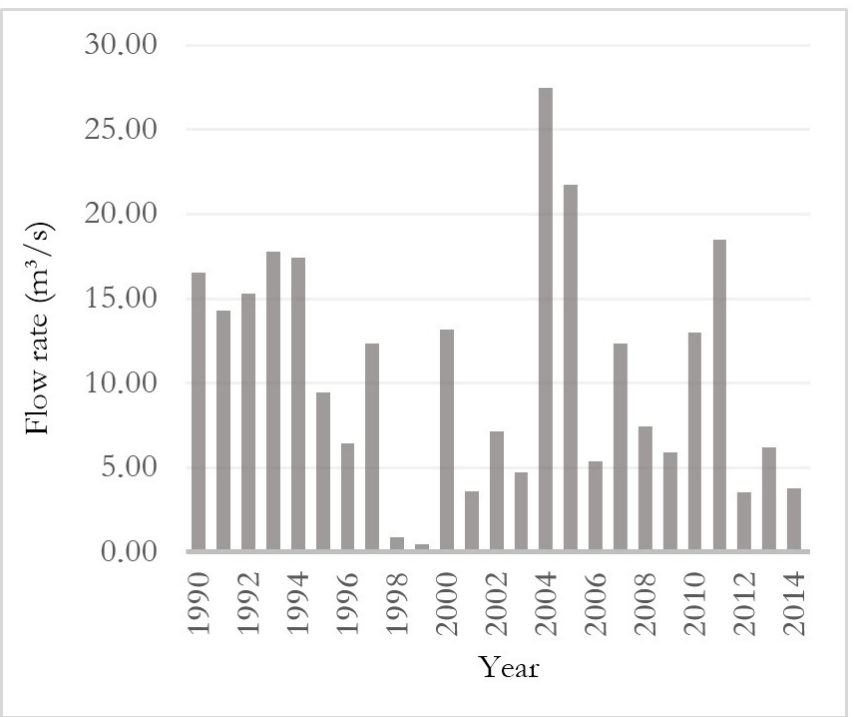

Figure 2. Average annual discharge of the Capibaribe river (fluviometric station 39187800).
Located in the lower course of the Capibaribe river, all the west navigation channel will be influenced by the tides phenomenon, more precisely the salt wedge, which is defined by the entrance of sea water through the mouth of the river during the high tide and by the flow of river water further upstream (SILVA, 2003). According to Silva (2003), during the ebb the margins can be exposed until the elevation of two meters.

In the course of the west navigation channel of the Capibaribe ten bridges still cross (Figure 3), in which eight still have auto-vehicles. The bridges still present elements of foundation submerged, which can alter the dynamic flow with the obstruction of the section and alteration of the position of the water line, in addition to promoting erosive behaviors next to the bridge abutments (LANÇA et al., 2005).

\section{Bathymetric surveys}

The data collection was carried out after the deepening dredgings, and was executed through successive bathymetric surveys, utilizing echobathymeter, satellite positioning system (GNSS), portable computer and other accessories.

The depth data (surveys), were determined by the single beam echobathymeter Bathy $500 \mathrm{MF}$, which allows digital readings of depth, integration with computer, resolution of $1 \mathrm{~cm}$ and precision of $0,1 \%$, which are adequate to the destination of the survey. To obtain the depths related to the level of the water, was necessary to obtain the value of immersion of the echobathymeter transducer, known as draft, which is associated to the assembly and weighing of the equipments in the vessel (FERREIRA et al., 2012). After the assembly of the equipments and coming of the team (helmsman, operator and assistant) on board of the survey ship in it's rightful places, the distance is adjusted between water blade and the echobathymeter transducer.

The calibration of the echobathymeter was executed with the help from a metallic disc, positioned in a known depth, so that the speed of sound was adjusted until the echobathymeter could inform the real depth.

The planimetric positioning of the surveys was executed with the GNSS Trimble DSM 232 equipment, with Omnistar correction service in real time, dispensing the use of a traditional RTK station. The synchronization and the register of position data supplied by the GNSS and of depth supplied by the echobathymeter were executed with the Trimble HydroPRO navigation software, and the treatment of dada (filtering, bathymetric reducing to the 'medium level of the sea' and export) was executed with Trimble HydroPRO navedit software.

During the execution of the bathymetric survey, the tide level was measured, where an auxiliary was responsible for the measurement of the level variation, taking notes every ten minutes of the elevation of the river level, related to a level reference (LR).

\section{Campaigns}

The bathymetric campaigns were done between the months of December 2013 to June 2014 (Table 1). From the West navigation axis were separated two areas for analysis, one of 


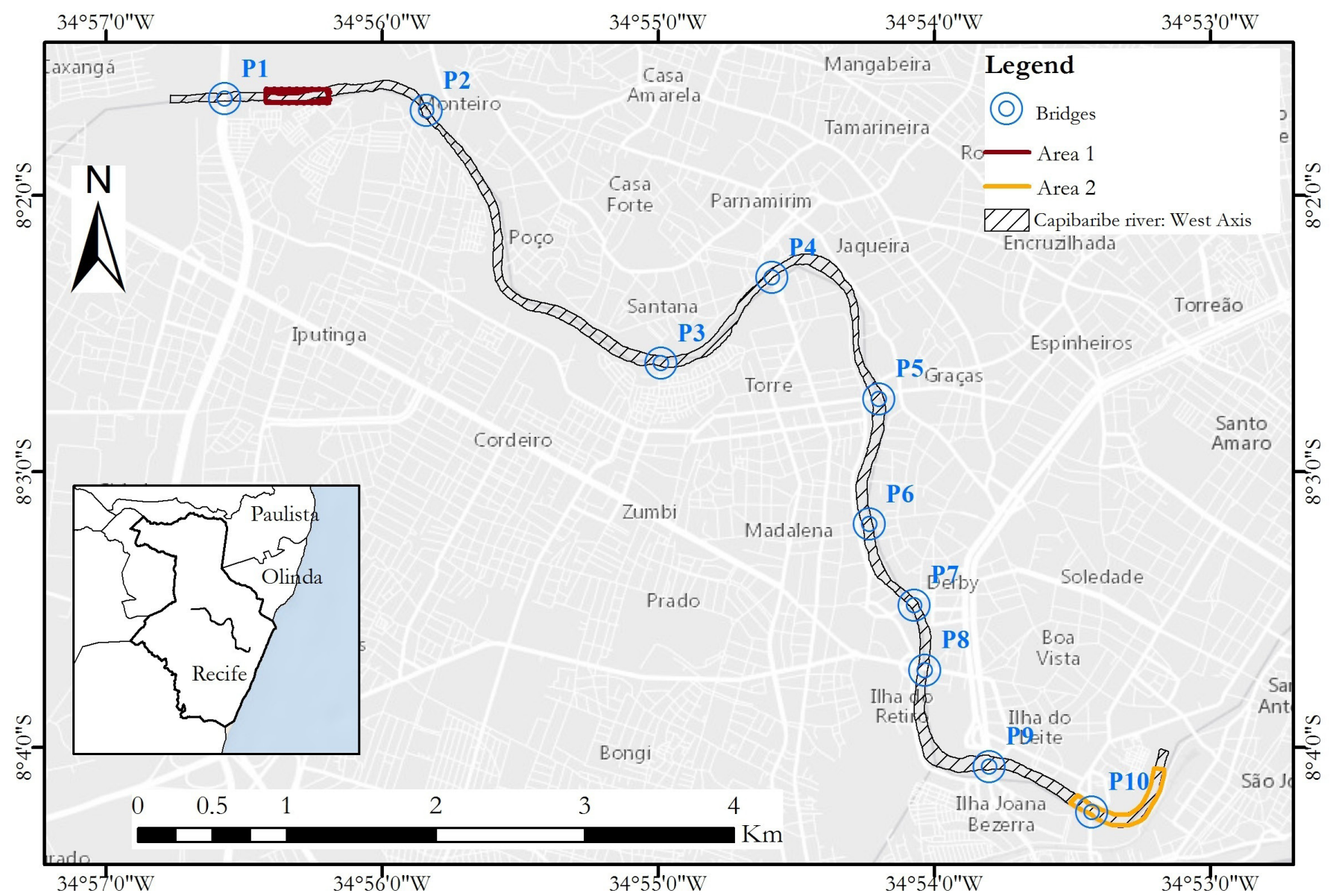

Figure 3. Study area: West navigation channel.

Table 1. Dates of the surveys.

\begin{tabular}{lcc}
\hline Section & Date 1 (PD1) & Date 2 (PD2) \\
\hline Area 1 & $02 / 08 / 2014$ & $05 / 05 / 2014$ \\
Area 2 & $12 / 28 / 2013$ & $05 / 31 / 2014$ \\
\hline
\end{tabular}

350 meters in the beginning of the navigation axis projected $(\mathrm{km} 1$ of the navigation channel) and one of 1000 meters positioned $10 \mathrm{~km}$ from the beginning of the navigation channel, this last one being a meander in the end of the western section. PD1 refers to the first scenario after the dredging activities and PD2 the second scenario after the dredgings.

\section{Data modeling}

For the representation of the bathymetric surface, the Krigagem interpolator ordinary was chosen, since this one produces good results for submerged surfaces and simplicity in it's application (MACHADO; SOUSA, 2003; GOMES et al., 2007; ALMEIDA, 2012).

The generation of the digital depth models, from which were extracted the geometric information for the plotting of the longitudinal and transverse profiles, were build with the ArcGIS/Esri software. In the building of the maps for the representation of the difference between surfaces of the riverbed, the Golden Surfer software, v.11, with the grid spacing set at 2 meters.

\section{RESULTS AND DISCUSSION}

\section{Analysis of the longitudinal and transverse profile}

The primitive longitudinal profile of the Capibaribe river (Figure 4) shows in the route of the navigation axis a subtle slope, with the greater elevation registered of $2.20 \mathrm{~m}$ and smallest of $-3.95 \mathrm{~m}$, as well as heterogeneity of the forms of the riverbed visible after the kilometer five. Some deposition trends/aggradation downstream of the confluence region with tax (PINTER et al., 2004) coming from the Apipucos weir, upstream of the winding stretches, in the places of flooding of the transversal section, and upstream of the bifurcation (PINTER et al., 2004) located in kilometer nine.

These irregularities of the longitudinal profile of the riverbed influence in the simulation of the water levels, mostly in flows of low intensity (SALEH et al., 2013).

The stretch meander located in the final kilometer of the West channel presents particularities with the worsening of the erosion, since in the curves of a river, the interaction between the vertical gradient of speeds and the curvature of the main 


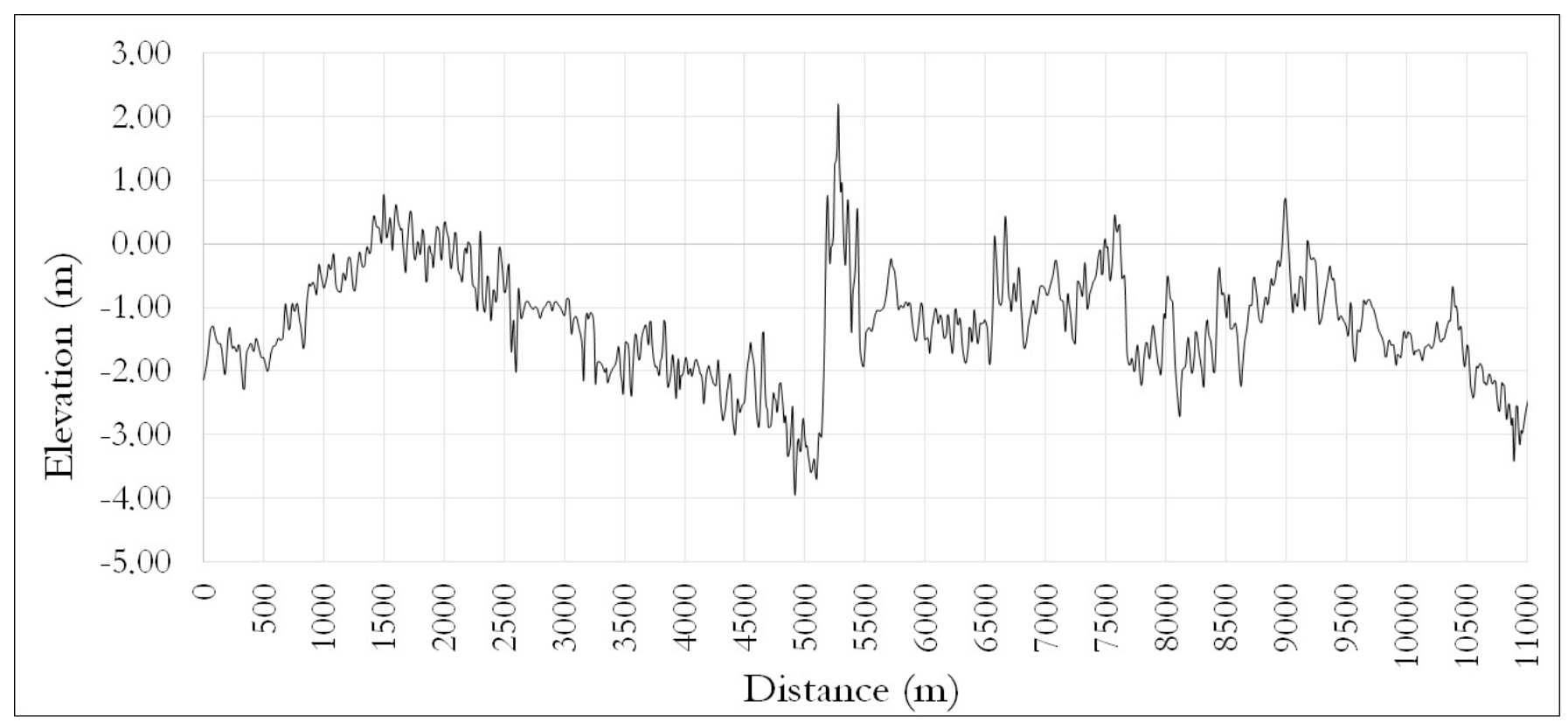

Figure 4. Primitive longitudinal profile of the Capibaribe riverbed in the west axis of the navigation channel.

flow originates the formation of secondary currents, potentiating the increase of the flow depth, the speeds and the shear stress entrainment in the outer zone of the curve (PINHEIRO, 2010).

After the dredging works, depositions and erosions were observed in some sections of the channel axis, which can be verified by the longitudinal profile in Figure 5 and Figure 6.

The effects of the deepening dredging in the change of the geometry of the channel were observed when analysed the profiles PD1 and PD2, for example, in Figure 5, when checked the increase in the slopes of the longitudinal profile and in the transversal profiles the decrease of the relation between length and depth. Similar observations were confirmed by Luo et al. (2007) in his research.

\section{Alterations in the riverbed geometry}

With the digital depth models generated in distinct periods, it was possible to visually analyze the geometric configuration of the Capibaribe riverbed, after the deepening dredgings (Figure 7 and Figure 8), as well as the evolution of the processes deposition / erosion alongside the longitudinal profile and cross sections. Temporal observations like this, based in the longitudinal profiles, are found to be important to propose containment measures to the processes silting and/or erosions (GIRELI et al. 2013).

For the calculation of the volume of the material deposited or eroded, was applied the difference between the two surfaces (grids) and further calculation of volume utilizing the methodology of trapezes. Based in the methodology of the trapezes (ODRESKI et al., 2003) the volume sedimented/eroded was estimated with the use of the volume calculation tool available in the Surfer software Versão11.

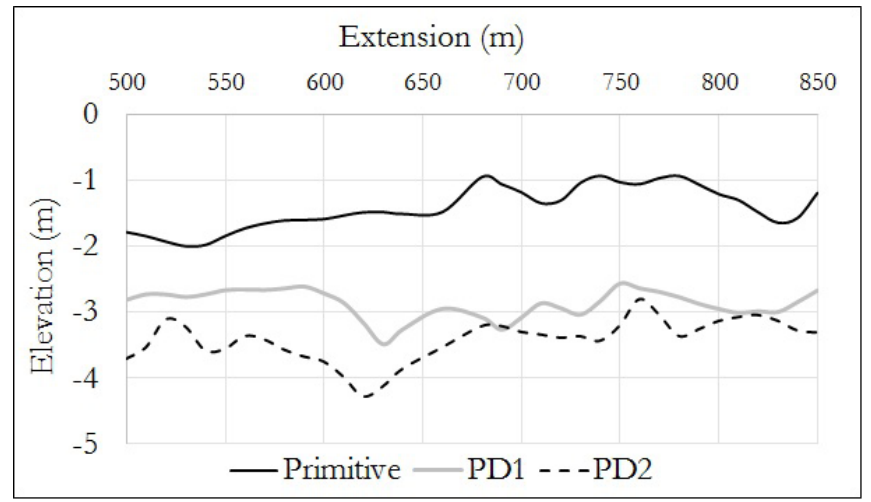

Figure 5. Evolution of the longitudinal profile in the section of $\mathrm{km} 1(500 \mathrm{~m}$ to $800 \mathrm{~m})$ after deepening dredging.

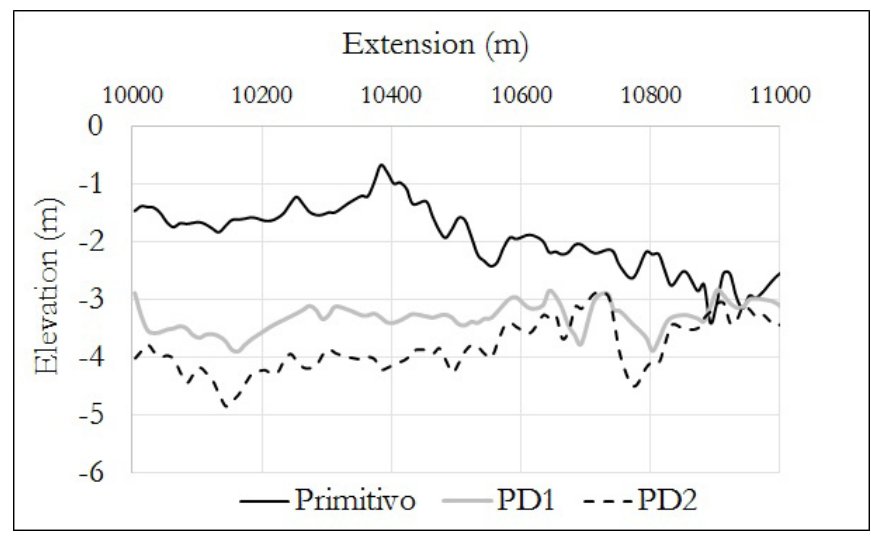

Figure 6. Evolution of the longitudinal profile from $\mathrm{km} 10$ to $\mathrm{km} 11$ after the deepening dredging. 


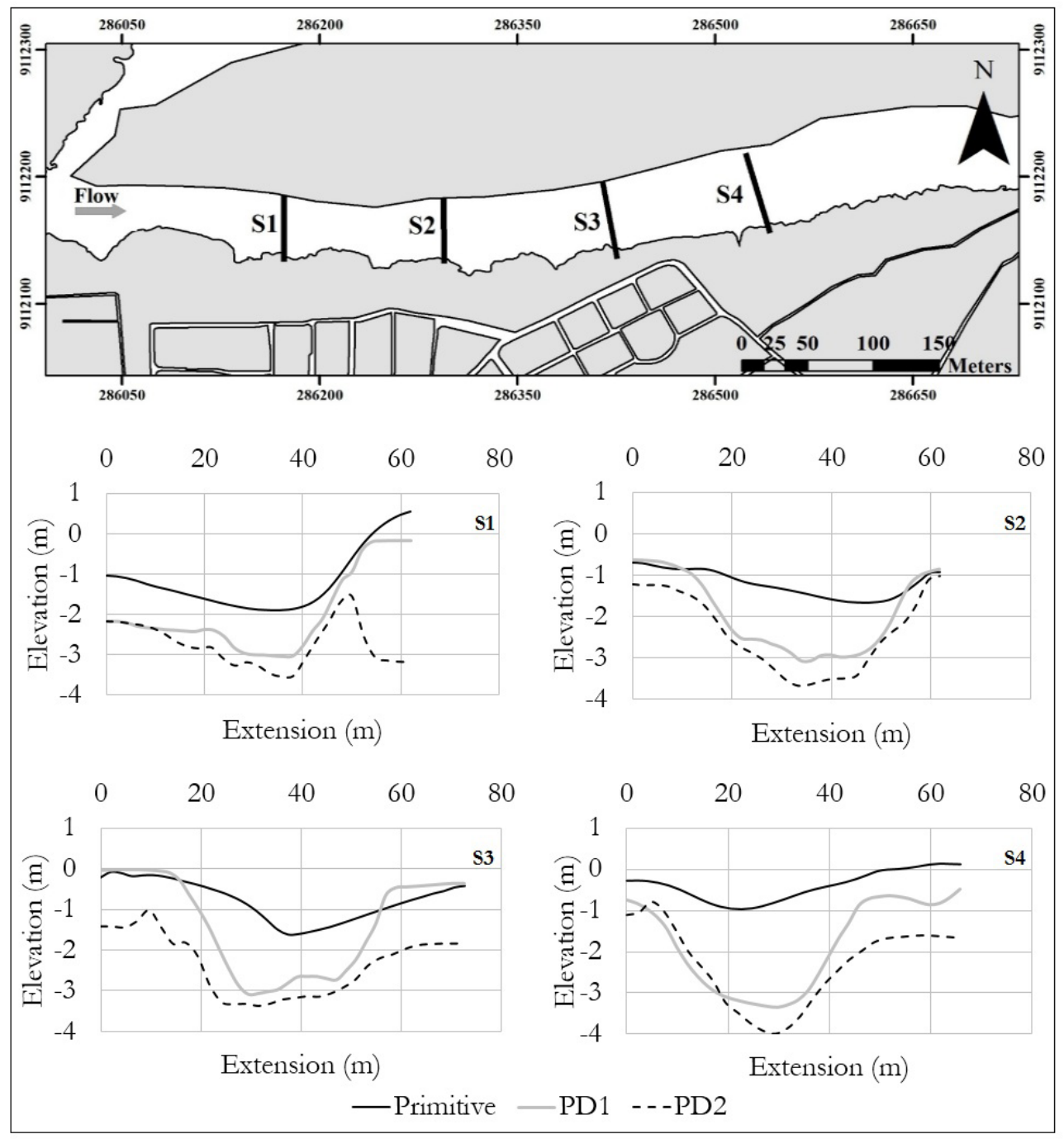

Figure 7. Location of the bathymetric profiles made and subsequent geometry of the cross sections in the study area 1.

The study area had a negative sediment balance in the order of 9000 cubic meters, that is, a greater removal occurred in relation to the amount deposited. In this high value, it appears that together with the natural process of aggradation/erosion, were made in the study area 1 point depth dredgings between 02/08/2014 and 05/05/2014.

In Figure 7, it is visible the difference between the geometry of the transversal profiles in scenarios PD1 and PD2, mostly in sections S1 and S3. In section S4, it is noted that even with the deepening dredgings, there were still places where there was aggradation of the riverbed in a short period of time.

In study area 2 , it was verified that between the period of $12 / 28 / 2013$ to $05 / 31 / 2014$, the volume of erosion did not exceed the volume of deposition, the balance result was positive, equal to 591.02 cubic meters of sedimented material, which to an area of 56,103.57 squared meters, stands for a sediment package of approximately 1 centimeter thick, if it was distributed evenly over the area.

Considering that the interval between the bathymetric campaigns of the study area 2 was 154 days, this means that the annual aggradation tax for the studied area would be 2.37 centimeters for the year 2014, if mantained the conditions of riverbed aggradation. It is considered a high rate (ODRESKI et al., 2003), although the anthropogenic activities like the dredgings, associated to the fact of the study area is located in the end of the dredged section, presents disorderly occupation in it's margins.

The transversal sections observed (Figure 8) suggest that the deepening of the riverbed caused the instability of the margins and migration of the sediment to the navigation channel quickly, contributing to the high aggradation rate in a short period of time. And because of that, the estimated rate can not extended to analyse an evolution of the profiles in the long run. Therefore, there is the need to constantly monitor the aggradation rate of the riverbed, to ensure the navigability conditions, margins protection, or maybe river works.

The alterations caused by the dredgings can be measured through the observation of the ratio between width and depth, as well as by the medium depth for both further scenarios of dredging activities (Table 2). In Area 1, the dredgings resulted in the medium change of depth $-1,93 \mathrm{~m}$ to $-2,46 \mathrm{~m}$ and in the proportion between width and depth of $38.21 \mathrm{~m} . \mathrm{m}^{-1}$ to $26.96 \mathrm{~m} \cdot \mathrm{m}^{-1}$. In area 2 , the changes were more sensitive with the medium depth maintenance 


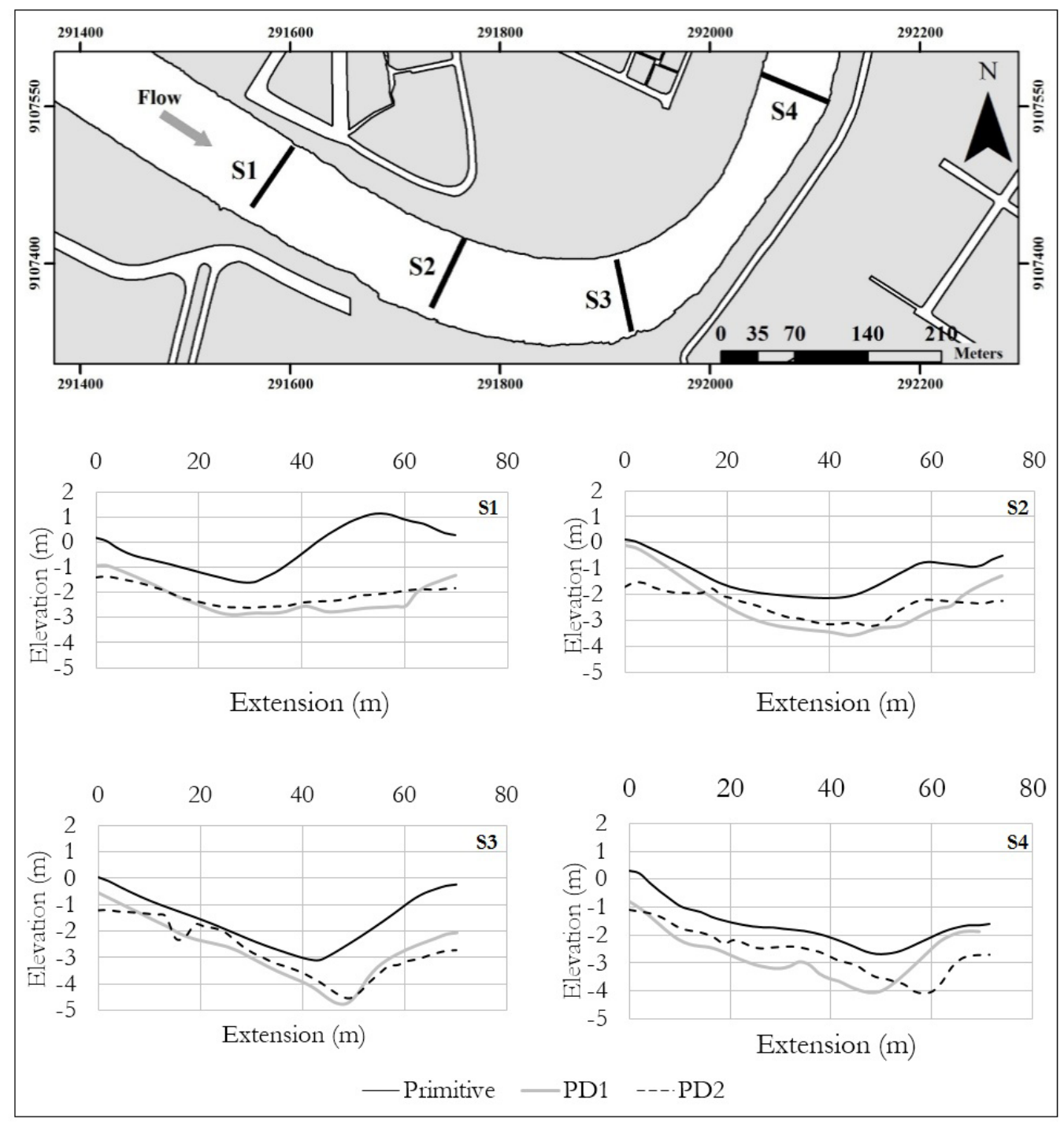

Figure 8. Location of the bathymetric profiles made and belonging geometry of the cross sections in the study area 2.

Table 2. Medium depth and ration between width and depth.

\begin{tabular}{|c|c|c|c|c|}
\hline & PD1 & PD2 & PD1 & PD2 \\
\hline Section & $\begin{array}{c}\text { Medium } \\
\text { Depth (m) }\end{array}$ & $\begin{array}{c}\text { Medium } \\
\text { Depth (m) }\end{array}$ & $\begin{array}{c}\text { W/D } \\
\left(\mathrm{m} \cdot \mathrm{m}^{-1}\right)\end{array}$ & $\begin{array}{c}\text { W/D } \\
\left(\mathrm{m} \cdot \mathrm{m}^{-1}\right)\end{array}$ \\
\hline Area 1 & -1.93 & -2.46 & 38.21 & 26.96 \\
\hline Area 2 & -2.85 & -2.85 & 28.27 & 29.16 \\
\hline
\end{tabular}

in $-2.85 \mathrm{~m}$ and initial proportion between width and depth of $28.27 \mathrm{~m} \cdot \mathrm{m}^{-1}$ reaching $29.16 \mathrm{~m} \cdot \mathrm{m}^{-1}$.

Figures 9 and 10 show the difference between the sediment volumes to indicate the intensity of the aggradation and erosion process that happened in the period. It was found that in the study area 1 , the aggradation was concentrated in the left margin of the river, while in the right margin, predominated the erosive process, indicating that beyond the timely dredgings made in the area, a change in the direction can be occurring in the flow channel.
The same findings were also verified by (GOGOI; GOSWAMI, 2013; MELVILLE; COLEMAN, 2000 apud PINHEIRO, 2010).

In the study area 2 , the sediment deposition process occurred evenly alongside all the meander section in the study area (Figure 10), with more sediment input in the internal section of the river bend, where the interaction between the vertical gradient of speeds and the curvature of the main flow originates the formation of crosscurrents, which potentiate the increase in the flow speed, and of the tension entrainment voltage to the outside of the curve. In this place, therefore, occurs the erosion of the riverbed in it's margin, and in the inner region, there is deposition of the sediment. The same results were also observed by (MELVILLE; COLEMAN, 2000 apud PINHEIRO, 2010). Pinter et al. (2004) observed bigger depositions in the half upstream the meander bends, which became a region of frequent deposition with an elevated sediment volume and great need of recurrent dredgings.

It is also visible a spot from sediments deposition upstream the Joaquim Cardozo bridge (P10) in Figure 3, and downstream the occurrence of erosion close to the margins. 


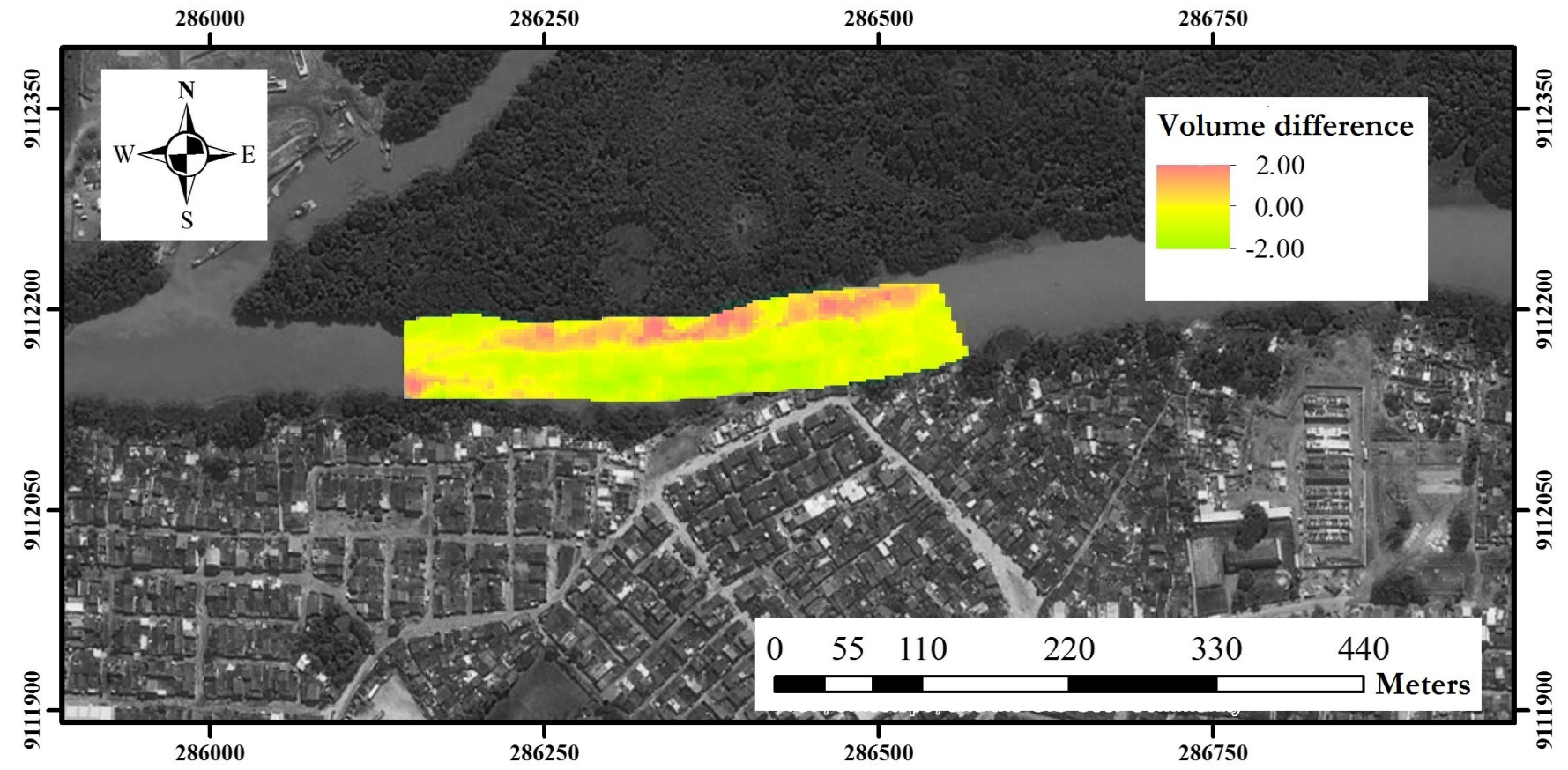

Figure 9. Map of the difference between aggradation/erosion volumes of the region in the study area 1 of Capibaribe river (initial section of the West navigation channel).

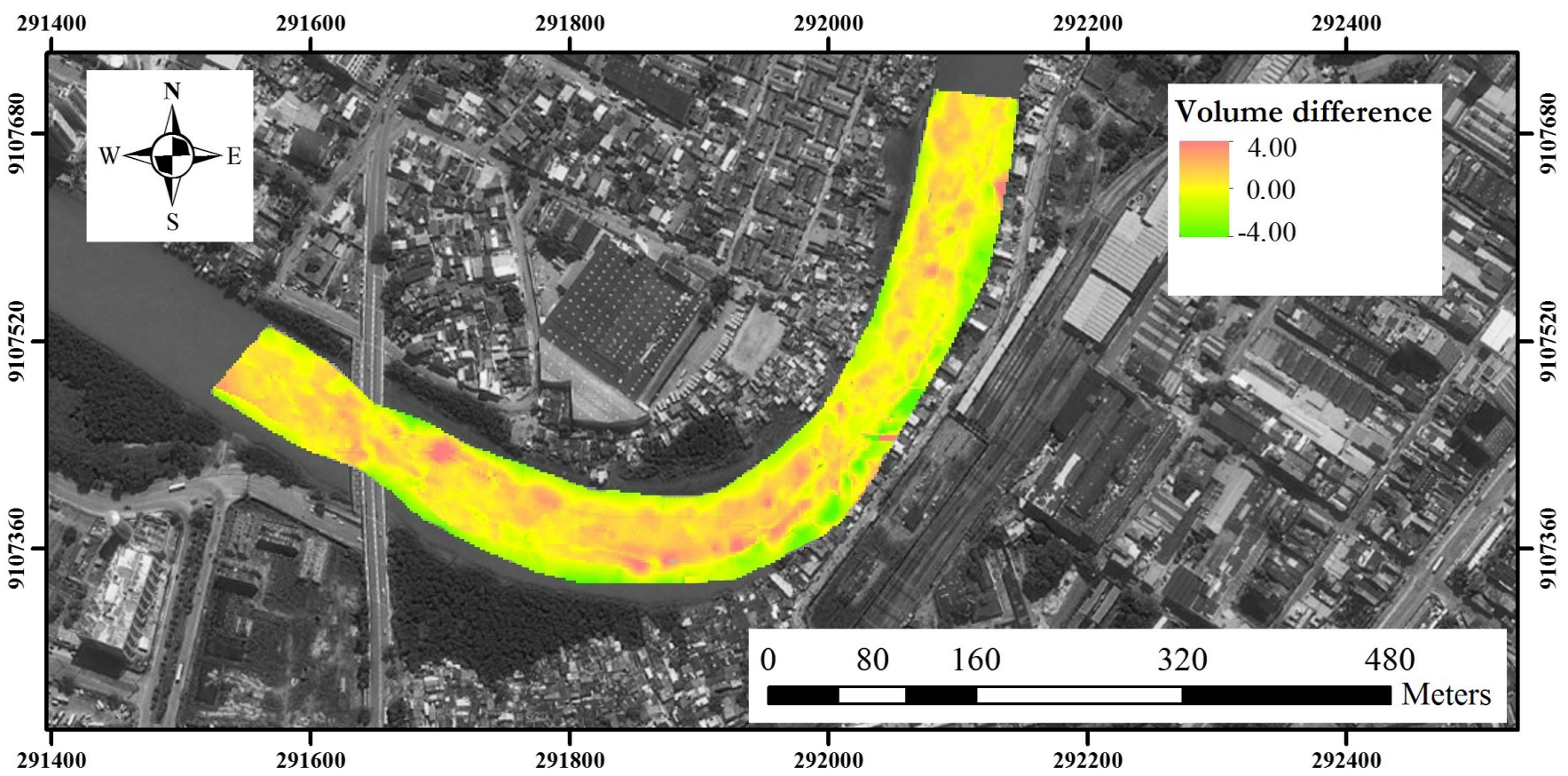

Figure 10. Map of the difference between aggradation/erosion volumes in the study area 2 of the Capibaribe river (final section of the West navigation channel).

\section{CONCLUSIONS}

The study about the geometry of the riverbed of a river makes possible to predict the behavior of the erosive processes and the deposition of sediments, which impact mainly in the management of water resources. In the case of Capibaribe river, has important functions, like in the dredging of stormwater, and now with the hope of serving as a river corridor for the transportation of passengers.

The dredgings are necessary to allow the safe movement of passengers of vessels. And the knowledge of the geometry of the riverbed after these interventions can give an estimate on 
the intensity of the of the maintenance dredgings, which will be necessary, and whose estimate can only be done when there is a systematic of riverbed aggradation.

The primitive profile of Capibaribe river shows that the forms of the riverbed are heterogeneous, mainly after kilometer five, whose geometric configuration presents itself with variations in width and meandering, with small slopes, unstable until kilometer eleven. The primitive profile, taken as a balance reference between the eroded and the deposited volume, will serve as a parameter to predict the locations with greater tendencies for aggradation, supplying important information for the control of the maintenance dredgings.

The longitudinal and transverse profiles were compared in two areas, located in the West navigation channel, one with 350 meters and another with 1000 meters, where it was found that in area 1 the erosion/removal of sediments exceeded the sedimentation/aggradation, indicating the occurrence of dredging in the interval between the two surveys associated to the natural processes.

In the study area 2, the sedimentation/aggradation process exceeded the removal/erosion one, with a volume equivalent to approximately a layer of $1 \mathrm{~cm}$ thick. The aggradation occurred homogeneously in the navigation channel, while the erosion positioned itself on the banks, more intensely on the right bank.

The deepening dredgings of the Capibaribe riverbed reached depths which offered navigation conditions, but the short interval between the bathymetric surveys indicated that the aggradation tax can represent the need for recurring maintenance dredgings in certain sections.

The behavior presented by the two areas was distinct. In area 1 , there was the increase in medium depth by $0.53 \mathrm{~m}$, jumping from $-1.93 \mathrm{~m}$ to $-2.46 \mathrm{~m}$, and the decrease in proportion between width and depth, from $38.21 \mathrm{~m} \cdot \mathrm{m}^{-1}$ to $26.96 \mathrm{~m} \cdot \mathrm{m}^{-1}$. In area 2, it was observed the maintaining of the average depth in $2.85 \mathrm{~m}$ and the proportion between width and initial depth of $28.27 \mathrm{~m} . \mathrm{m}^{-1}$ reaching $29.16 \mathrm{~m} \cdot \mathrm{m}^{-1}$.

The dredgings done in the Capibaribe river will have positive and negative impacts. The increase of the flow section will bring benefits in the periods of high unloads. Although attention should be paid to the riverside buildings, which can suffer with the instability of the banks and the many bridges that cut the navigation channel, and whose foundations can suffer with the increase of the erosive processes.

\section{REFERENCES}

ALFREDINI, P. Obras e Gestão de Portos e Costas: a técnica aliada ao enfoque logístico e ambiental. São Paulo: Edgard Blücher, 2005.

ALMEIDA, L. M. Análise de metodologias para o cálculo da descarga de fundo, aplicada ao Rio Doce, ES. 2012. 151 f. Dissertação (Mestrado em Engenharia Ambiental) - Universidade Federal do Espírito Santo, Goiabeiras, 2012.

ANA - AGÊNCIA NACIONAL DAS ÁGUAS. Séries temporais da estação fluviométrica de código n³9187800. Brasília, 2015. Available from: <www.ana.gov.br/hidroweb>. Access on: 12 dez. 2015.
APAC - AGÊNCIA PERNAMBUCANA DE ÁGUAS E CLIMA. Bacia bidrográfica do rio Capibaribe. Recife, 2014. Available from: $<$ http://www.apac.pe.gov.br/pagina.php?page_id=5\&subpage_ id=14>. Access on: 12 dez. 2014.

ARENTZ, M. F. R. A modelagem hidrológica como auxílio à navegação no canal norte do estuário do Amazonas. 2009. 166 f. Dissertação (Mestrado em Engenharia Oceânica) - Universidade Federal do Rio de Janeiro, Rio de Janeiro, 2009.

CARVALHO, N. O. Hidrossedimentologia prática. 2. ed. Rio de Janeiro: Interciência, 2008. 600 p.

FERrEIRA, I. O.; RODRIGUES, D. D.; SANTOS, A. P. Levantamento batimétrico automatizado aplicado à gestão de recursos hídricos. Estudo de caso: Represamento do Ribeirão São Bartolomeu, Viçosa-MG. In: SIMPÓSIO BRASILEIRO DE CIÊNCIAS GEODÉSICAS E TECNOLOGIAS DA GEOINFORMAÇÃO., 4, 2012, Recife. Anais... Recife: Programa de Pós-Graduação em Ciências Geodésicas e Tecnologias da Geoinformação, 2012. p. 1-8.

FERREIRA, I. O. Coleta, processamento e análise de dados batimétricos visando a representação computacional do relevo submerso utilizando interpoladores determinísticos e probabilísticos. 2013. 70 f. Dissertação (Mestrado em Engenharia Civil). Programa de Pós-graduação em Engenharia Civil, Universidade Universidade Federal de Viçosa, Viçosa, 2013.

GIRELI, T. Z.; MENDONÇA, P. V.; MOREIRA, M. C. A. Proposta de diques e espigões para minimizar o assoreamento no trecho de remanso do reservatório de Barra Bonita. In: SIMPÓSIO BRASILEIRO DE RECURSOS HÍDRICOS, 20., 2013, Bento Gonçalves. Anais... Bento Gonçalves: Associação Brasileira de Recursos Hídricos, 2013. p. 1-8.

GIRELI, T. Z.; VENDRAME, R. F. Aprofundamento do Porto de Santos: uma análise crítica. Revista Brasileira de Recursos Hidricos, v. 17, n. 3, p. 49-59, 2012. http://dx.doi.org/10.21168/rbrh. v17n3.p49-59.

GOGOI, C.; GOSWAMI, D. C. A study on bank erosion and bank line migration pattern of the Subansiri River in Assan using Remote Sensing and GIS Tecnology. The Internacional Journal of Engineering and Science, v. 2, n. 9, p. 1-6, 2013.

GOMES JUNIOR, F. C. Relatório de impacto ambiental: projeto de navegabilidade dos rios Capibaribe e Beberibe. Recife: Caruso Jr. Estudos Ambientais \& Engenharia Ltda, 2012.

GOMES, M. P.; VITAL, H.; MACEDO, J. W. P. Aplicação da geoestatística na filtragem de dados batimétricos e altimétricos na Bacia Potiguar. Revista de Geologia, v. 20, n. 2, p. 243-254, 2007.

GUERRA, A. J. T.; CUNHA, S. B. Geomorfologia: uma atualização de bases e conceitos. Rio de Janeiro: Bertrand Brasil, 2012. 
LANÇA, R.; MARTINS, C.; MENDES, J. Metodologia para o estudo bidráulico e sedimentológico em pontes: aplicação à Ribeira de Oeiras, entre as localidades de Corte de Pão e Água e de Morena, concelho de Mértola. Faro: Universidade do Algarve, 2005.

LUO, X.; ZENG, E. Y.; JI, R.; WANG, C. Effects of in-channel sand excavation on the hydrology of the Pearl River Delta, China. Journal of Hydrology, v. 343, n. 3-4, p. 230-239, 2007. http://dx.doi. org/10.1016/j.jhydrol.2007.06.019.

MACHADO, P. B.; SOUZA, A. J. A geoestatística como ferramenta de estudo da batimetria na vertente continental portuguesa. Finisterra, v. XXXVIII, n. 76, p. 95-107, 2003.

MARTINS, D. P. Dinâmica das formas de leito e transporte de carga de fundo no alto Rio Paraná. 2004. 66 f. Dissertação (Mestrado em Geografia). Programa de Pós-graduação em Geografia, Universidade Estadual de Maringá, Maringá, 2004.

MONTEIRO, L. H. U.; SILVA, G. S.; LIMA, L. L. L.; COUTINHO, P. N. Estudos hidrodinâmicos e hidroquímicos do estuário do rio Capibaribe e bacia do Pina, Recife-PE. In: SIMPÓSIO BRASILEIRO DE OCEANOGRAFIA, 5., 2011, Santos. Anais... São Paulo: Instituto Oceanográfico, Universidade de São Paulo, 2011. Available from: <http://vsbo.io.usp.br>. Access on: 12 nov. 2015.

NITTROUER, J. A.; ALLISON, M. A.; CAMPANELLA, R. Bedforms transport rates for the lowermost Mississippi river. Journal of Geophysical Research, v. 113, n. 3, p. 2156, 2008. http:/ / dx.doi.org/10.1029/2007JF000795.

ODRESKI, L. L. R.; SOARES, C. R.; ANGULO, R. J.; ZEM, R. C. Taxas de assoreamento e a influência antrópica no controle da sedimentação da Baía de Antonina - Paraná. Boletim Paranaense de Geociências, n. 53, p. 7-12, 2003.

OLIVEIRA, L. R. L. Geomorfologia fluvial e navegabilidade do baixo curso do rio Tocantins. 2010. 108 f. Dissertação (Mestrado em Geologia). Programa de Pós-graduação em Geologia, Processamento de
Dados e Análise Ambiental, Universidade Universidade de Brasília, Brasília, 2010.

PINHEIRO, R. M. C. Estudo experimental de erosão em pilares de pontes. 2010. 166 f. Dissertação (Mestrado em Engenharia Civil) - Departamento de Engenharia Civil, Faculdade de Engenharia, Universidade do Porto, Porto, 2010.

PINTER, N.; MILLER, K.; WLOSINSKI, J. H.; VAN DER PLOEG, R. R. Recurrent shoaling and channel dredging, Middle and Upper Mississippi River. Journal of Hydrology, v. 290, n. 3-4, p. 275-2, 2004. http://dx.doi.org/10.1016/j.jhydrol.2003.12.021.

SALEH, F.; DUCHARNE, A.; FLIPO, N.; OUDIN, L.; LEDOUX, E. Impact of riverbed morphology and water levels simulated by a 1D Saint-Venant hydraulic model at regional scale. Jounal of Hydrology, v. 476, p. 169-177, 2013. http://dx.doi.org/10.1016/j. jhydrol.2012.10.027.

SILVA, J. P. Sedimentologia, batimetria, qualidade da água e vulnerabilidade do rio Capibaribe na cidade do Recife. 2003. 101 f. Dissertação (Mestrado em Geociências) - Programa de Pós-graduação em Geociências, Universidade Federal de Pernambuco, Recife, 2003.

STRASSER, M. A. Estudo da geometria das formas de fundo no curso médio do rio Amazonas. 2002. 113 f. Dissertação (Mestrado em Engenharia Civil) - Programa de Pós-graduação de Engenharia, Universidade Federal do Rio de Janeiro, Rio de Janeiro, 2002.

\section{Authors contributions}

Rafael Roney Camara de Melo: paper's conception; literature search; data collection, processing and analysis; writing and formatting of the paper.

Jose Roberto Gonçalves de Azevedo: Advisor Professor; paper's conception; Revision and formatting of the paper. 